\title{
Chemical and Mechanical Treatment of Banana Waste to Develop an Efficient Insulating Material
}

Anand Parkash*

Department of Chemical Engineering, Mehran University of Engineering and Technology, Jamshoro, Pakistan

\begin{abstract}
Large quantity of agricultural waste accompanied with other waste materials like plastics are disposed off abundantly without any pretreatment or alternative utilization in Pakistan. It creates a series of environmental and economical problems. Due to lake of information and less focus on R \& Ds on this treasure not only wastes huge amount of money on their improper consumption of budget but also close the paths for optimized utilization of energy resources. This research work is purposed not only to provide an alternative use of such disposable materials but also focuses on the optimization of use of energy resources in process industries. In this research work the agricultural waste like banana leaves with binder like epoxy and waste plastics were utilized to prepare an efficient insulating material with competitive insulating properties. The prepared material was analyzed with several common standard tests available for commercial insulating materials. On the basis of these test this researched insulating material was found to be more reliable and of equal standards.
\end{abstract}

Keywords: Banana waste; Insulating materials; Binders; Energy

\section{Introduction}

Various materials such as mineral fibers, fiber glass or rock wool are used for the preparation of insulating material in order to provide insulation property. Insulation is used to recover heat losses in chemical processes, steam boilers, insulating covers to hot pipelines, insulating coating of process equipment, to maintain homes room temperature or insulating covers for engineering equipment's. The cost, insulating properties and effectiveness of insulating material is the key factor in industrial applications. In this work, effect of fiber moisture, Density of Board, and time of pressing on conductivity and properties of material were also examined [1]. The thermal conductivity of a material had a direct relation with the Board density. It was also determined that this sort of substance made was environmental favorable and friendly. An insulating material without using calcium chloride from coconut husk [2]. The density of the coconut husk cement composites were relatively low due to which it is further suitable as insulating material in weighty and large construction [3]. The consequence of particle mass of Coconut husk was seen significant on the sorption and strength goods of the composites materials [4]. Relatively thicker in size, stiffer and stronger composites material became potential from the minor in size husk particles. Introduction of $3.2 \%$ calcium chloride had substantial positive possessions on the density of material and also the absorption of water of the coconut husk cements composites materials [5]. An insulating stuff from a non-fired route and non-steam-cured by sorel cement, fly-ash usage and solution of hydrogen peroxide. The physical and chemical properties such as bending strength, water resistance superficial density, compressive strengths, thermal conductivity, and tolerance of that stuff were analyzed [6,7]. It was claimed that mater to be low weight, high strength, and appreciable heat resistivity. Considerable amount of fly ash in this material helped in reducing its cost and environment suitable constructive material $[8,9]$. The increasing of percentage of the Raw material, Particleboard's density decreased which cause to reduce the thermal conductivity of material [10]. Analyzed showed that the particle boards were inexpensively and environmentally reasonable [11]. In his research various arrangement of mixture were developed for CLSM and were verified in the laboratory for various properties, such as flow strength, behavior of stress-strain, density, unconfined compressive, ability, water absorption. Evaluation was performed of these samples, rice husk and fly ash for capability to produce feasible (CLSM). It was observed that this mixture of byproduct materials such as rice husk, ash, dust were successful materials to be used in CLSM.

\section{Materials and Methods}

The cultivation of banana trees is higher in the Sindh region. Millions tones of banana waste is generated and burned into open atmosphere, which leads in environmental pollution. There is no proper utilization of this waste. In this regard, study was taken to prepare advanced insulating materials from the banana waste. For this study, four steps were taken such as collection of material, pretreatment of banana waste leaves, preparation of insulating material and determination of properties [12,13].

\section{Collection of materials}

The desired quantities $(3 \mathrm{~kg}$ ) of fresh green banana leaves were collected from the agricultural areas of district Naushero Feroze, Sindh. The samples were properly sealed in plastic bags and were kept in laboratory at room temperature.

\section{Banana pretreatment}

The fresh and green banana waste samples were pre-treated in order to make suitable and effective raw material for preparation of long lasting insulating material. The pretreatment process of this material consisted of soaking, washing, drying, grinding and sieving [14].

\section{Soaking}

The collected samples were washed with double distilled water in

*Corresponding author: Anand Parkash Department of Chemical Engineering, Mehran University of Engineering and Technology, Jamshoro, Pakistan, E-mail: parwani_anand@yahoo.com

Received: August 31, 2015; Accepted: October 26, 2015; Published October 29, 2015

Citation: Parkash A (2015) Chemical and Mechanical Treatment of Banana Waste to Develop an Efficient Insulating Material. Biochem Anal Biochem 4: 220 doi:10.4172/2161-1009.1000220

Copyright: ( 2015 Parkash A. This is an open-access article distributed under the terms of the Creative Commons Attribution License, which permits unrestricted use, distribution, and reproduction in any medium, provided the original author and source are credited. 
order to remove dust particle impurities. Then washed banana leaves were cut into short pieces with the help of laboratory pair of scissors in order to provide proper penetration of soaking solution. The hard fiber materials of banana leaves were emitted in order to avoid any complexity. The solution of $2 \% \mathrm{NaOH}$ was prepared by dissolving 20 $\mathrm{g}$ of $\mathrm{NaOH}$ (Merck, Germany) in $1000 \mathrm{~mL}$ of distilled water at room temperature. Cut pieces of banana waste were dipped into prepared solution of $\mathrm{NaOH}$ for $24 \mathrm{hrs}$ at room temperature in order to remove lignin from this waste material in order to avoid any fungal or bacterial effect $[14,15]$.

\section{Washing}

After soaking process of banana waste, soaked material was properly washed with doubled distilled water for 6 hrs by dipping it into $1000 \mathrm{~mL}$ beaker in order to remove the concentration of $\mathrm{NaOH}$ and lignin from the material.

\section{Drying}

The washed banana waste material was dried in laboratory Oven (Lo-201C, The Grieve Corporation, USA) at temperature of $60^{\circ} \mathrm{C}$ for $20 \mathrm{hrs}$ in order to remove moisture content. The initial and final weight of banana waste was measured before and after drying of samples using laboratory analytical balance.

\section{Grinding and sieving of the material}

The dried pre-treated banana waste was grinded with help of ball mill at specific revolution speed. The waste was grinded into fine particle size. The grinded samples were sieved through RO-Tap Type Sieve shaker (A-871205, Heiko Seisakusho Tokyo Japan) at $290 \mathrm{rpm}$ speed. Fine banana powder (mesh 200, Aperture 25 um, wire dia, $25 \mu \mathrm{m}$ ) was collected from testing Sieve (IIDA manufacturing co.ltd Osaka, Japan).

\section{Preparation of insulating materials}

The fine powder of banana waste was converted into effective insulating material by use of epoxy resin and used plastic as binder at different concentrations (5\%,10\% and $15 \%$, and $20 \%$ ). The banana powder along with above stated concentration of binders was mixed with each other by use of Advantech Midget Stirrer (Model: Mz-800H). The prepared binding and insulating material sample was mould in desired shape by compressing using Buehler Simpllmet-II Press Mold. The pellets of insulating material were prepared in cylinder shape having dimensions of thickness $(0.015 \mathrm{~m})$, diameter $(0.025 \mathrm{~m})$ and area $\left(0.00117 \mathrm{~m}^{2}\right)$. After preparation of insulating materials at different weight ratios of banana waste and binders, the prepared insulating material samples were stored into silica desiccators in order to protect material from moisture effect.

\section{Results and Discussion}

\section{Density}

The density of banana waste composite material with epoxy resin and waste plastic binders were calculated. The volume of all the samples was kept constant $\left(1.60 \times 10^{-3} \mathrm{~cm}^{3}\right)$. The sample was weighed carefully three times each for accuracy. Moreover the dimensions of the sample were re-verified for accurate results. By simple mass per unit calculation the density of all the samples were noted.

Density of composites of Banana waste and Epoxy as binder of $4: 1$ ratio of sample $1-5$ were calculated as $1.120,1.117,1.101,1.107$, and $1.115 \mathrm{~g} / \mathrm{cm}^{3}$ respectively. Densities of $85-15$ ratio of sample 1 to 5 varied from 1.100 to $1.117 \mathrm{~g} / \mathrm{cm}^{3}$. Similarly in ratios $90-10$ and $95-05$, the densities were found from 1.085 to $1.115 \mathrm{~g} / \mathrm{cm}^{3}$ (Table 1).

Density of composites of Banana waste and waste plastic as binder of 4:1 ratio of sample 1-5 were 1.076, 1.063, 1.049, 1.064, and $1.070 \mathrm{~g} /$ $\mathrm{cm}^{3}$ respectively. Densities of $85-15$ ratio of sample 1-5 varied from 1.057 to $1.093 \mathrm{~g} / \mathrm{cm}^{3}$. Similarly in ratios $90-10$ and $95-05$, the densities were in range from 1.065 to $1.102 \mathrm{~g} / \mathrm{cm}^{3}$ (Table 2). It was reported that the samples of composite material with binder as epoxy were denser compared to the waste plastic bonded sample. It was further observed that on decreasing the concentration of binder the overall density of the composite decreased [12]. In first case (Banana + Epoxy), it was found that on increase in fiber concentration the density of composite material decreases. This is due to higher density of epoxy than banana fiber. In second case (Banana + Plastic waste), it reverse the order i.e. on increase in fiber concentration the density of composite increases [11]. This is due to higher density of banana fiber than plastic waste. The density of durian UF boards is in the range of $0.8-0.9 \mathrm{~g} / \mathrm{cm}^{3}$

\section{Water absorption capacity}

Water absorption capacity is another crucial factor to be taken into account when considering the analysis of an insulating material. The effect is presented in Tables 3 and 4 .

Water absorption percent of composites of Banana-Epoxy of $4: 1$ ratio of sample $1-5$ were $2.231,2.604,2.250,2.361$, and $2.413 \%$ respectively. The absorption percent in sample having $85-15$ ratio of sample $1-5$ varied from 2.331 to $2.723 \%$. Similarly in ratios $90-10$ and $95-05$, the absorption percents were in a range of 2.430 to $2.961 \%$ (Table 3).

\begin{tabular}{|c|c|c|c|c|}
\hline S.No & $\begin{array}{c}\text { Composite 1 } \\
\text { Ba+Ex } \\
(\mathbf{8 0 \%} \text { and 20\%) }\end{array}$ & $\begin{array}{c}\text { Composite 2 } \\
\text { Ba+Ex } \\
(\mathbf{8 5 \%} \text { and 15\%) }\end{array}$ & $\begin{array}{c}\text { Composite 3 } \\
\text { Ba+Ex } \\
\mathbf{( 9 0 \%} \text { and 10\%) }\end{array}$ & $\begin{array}{c}\text { Composite 4 } \\
\text { Ba+Ex } \\
\mathbf{( 9 5 \% ~ a n d ~ 0 5 \% ) ~}\end{array}$ \\
\hline 1 & 1.120 & 1.117 & 1.115 & 1.113 \\
\hline 2 & 1.117 & 1.113 & 1.108 & 1.104 \\
\hline 3 & 1.101 & 1.096 & 1.091 & 1.085 \\
\hline 4 & 1.107 & 1.105 & 1.102 & 1.100 \\
\hline 5 & 1.115 & 1.112 & 1.109 & 1.106 \\
\hline
\end{tabular}

Table 1: Density $\left(\mathrm{g} / \mathrm{cm}^{3}\right)$ of composites of banana waste and epoxy as binder.

\begin{tabular}{|c|c|c|c|c|}
\hline S.No & $\begin{array}{c}\text { Composite 1 } \\
\text { Ba+WP } \\
\text { (80\% and 20\%) }\end{array}$ & $\begin{array}{c}\text { Composite 2 } \\
\text { Ba+WP } \\
\mathbf{( 8 5 \%} \text { and 15\%) }\end{array}$ & $\begin{array}{c}\text { Composite 3 } \\
\text { Ba+Ex } \\
\mathbf{( 9 0 \% ~ a n d ~ 1 0 \% ) ~}\end{array}$ & $\begin{array}{c}\text { Composite 4 } \\
\text { Ba+WP } \\
\mathbf{( 9 5 \% ~ a n d ~ 0 5 \% ) ~}\end{array}$ \\
\hline 1 & 1.076 & 1.085 & 1.093 & 1.102 \\
\hline 2 & 1.063 & 1.072 & 1.081 & 1.091 \\
\hline 3 & 1.049 & 1.057 & 1.065 & 1.072 \\
\hline 4 & 1.064 & 1.072 & 1.080 & 1.089 \\
\hline 5 & 1.070 & 1.078 & 1.087 & 1.095 \\
\hline
\end{tabular}

Table 2: Density $\left(\mathrm{g} / \mathrm{cm}^{3}\right)$ of composites of banana waste and waste plastic as binder.

\begin{tabular}{|c|c|c|c|c|}
\hline S.No & $\begin{array}{c}\text { Composite 1 } \\
\text { Ba+Ex } \\
(\mathbf{8 0 \%} \text { and 2\%) }\end{array}$ & $\begin{array}{c}\text { Composite 2 } \\
\text { Ba+Ex } \\
(\mathbf{8 5 \%} \text { and 15\%) }\end{array}$ & $\begin{array}{c}\text { Composite 3 } \\
\text { Ba+Ex } \\
(\mathbf{9 0 \%} \text { and 10\%) }\end{array}$ & $\begin{array}{c}\text { Composite 4 } \\
\text { Ba+Ex } \\
\text { (95\% and 05) }\end{array}$ \\
\hline 1 & 2.231 & 2.331 & 2.430 & 2.530 \\
\hline 2 & 2.604 & 2.723 & 2.842 & 2.961 \\
\hline 3 & 2.250 & 2.352 & 2.455 & 2.558 \\
\hline 4 & 2.361 & 2.469 & 2.576 & 2.683 \\
\hline 5 & 2.413 & 2.523 & 2.632 & 2.741 \\
\hline
\end{tabular}

Table 3: Percentage of water absorption of composites of banana waste and epoxy as binder. 
Water absorption percent of composites of Banana-waste plastic of $4: 1$ ratio of sample 1-5 were reported in range from 2.231, 2.604, 2.240, 2.361 , and $2.413 \%$ respectively. The absorption percent in sample having $85-15$ ratio of sample $1-5$ varied from 2.330 to $2.723 \%$. Similarly in ratios 90-10 and 95-05, the absorption percents were in a range of 2.430 to $2.961 \%$ (Figure 1 ). The effect of water absorption is vital in case the stuff that has been developed when used for applications comes in contact of water. This significant increase with regards to the epoxy resin is due to the detail that here the present banana fibers have maximum capacity of water absorption in comparison to the silica and the resin particles [13-15].

When concentration of the binders i.e Epoxy/plastic waste in composite material preparation was decreased, the water absorption rate of these composite materials was increased. Because fiber have more water affinity property $[9,10]$. As compared both, Composite material $(\mathrm{BN}+\mathrm{EPX})$ have higher water absorption capacity. The moisture absorption of the films increased as the amount of banana starch was increased. The films containing $20 \%$ banana starch absorbed moisture up to $4.5 \%$ (Ahtong and charoenkongthum). The water absorption is $2.9 \%$ of banana, where epoxy has $0.647 \%[7,8]$.

\section{Thermal conductivity}

It was found that the thermal conductivity of banana-epoxy composite material ranged from 0.366 to $0.456 \mathrm{~W} / \mathrm{K}$ (Table 5). The thermal conductivity of the BA-EP decreases if the concentration of cellulosic fiber is increased. These values of thermal conductivity were found satisfactory when compared with other researcher materials $[4,5]$.

It was observed the thermal conductivity of banana-waste plastic

\begin{tabular}{|c|c|c|c|c|}
\hline S.No & $\begin{array}{c}\text { Composite1 } \\
\text { Ba+WP } \\
(\mathbf{8 0 \%} \text { and 20\%) }\end{array}$ & $\begin{array}{c}\text { Composite 2 } \\
\text { Ba+WP } \\
\text { (85\% and 15\%) }\end{array}$ & $\begin{array}{c}\text { Composite 3 } \\
\text { Ba+WP } \\
\text { (90\% and 10\%) }\end{array}$ & $\begin{array}{c}\text { Composite 4 } \\
\text { Ba+WP } \\
\text { (95\% and 05\%) }\end{array}$ \\
\hline 1 & $2.231 \%$ & $2.330 \%$ & $2.430 \%$ & $2.530 \%$ \\
\hline 2 & $2.604 \%$ & $2.723 \%$ & $2.840 \%$ & $2.961 \%$ \\
\hline 3 & $2.240 \%$ & $2.350 \%$ & $2.460 \%$ & $2.560 \%$ \\
\hline 4 & $2.361 \%$ & $2.460 \%$ & $2.500 \%$ & $2.650 \%$ \\
\hline 5 & $2.413 \%$ & $2.530 \%$ & $2.640 \%$ & $2.750 \%$ \\
\hline
\end{tabular}

Table 4: Percentage of water absorption of composites of banana waste and waste plastic as binder.

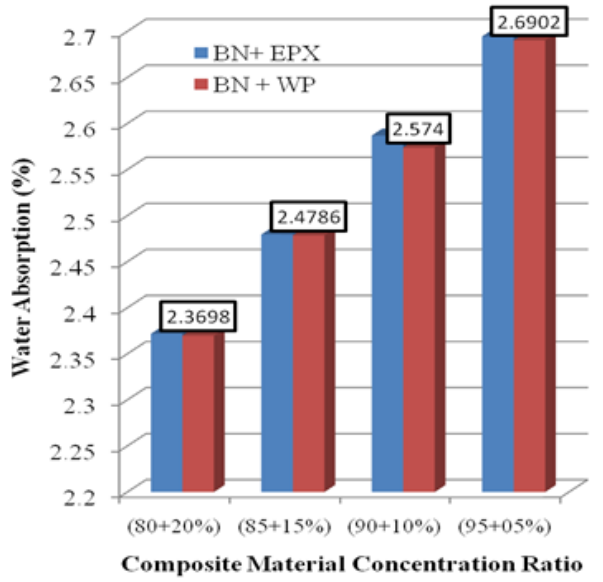

Figure 1: Comparison of water absorption $\%$ of composite materials.

\begin{tabular}{|c|c|c|c|c|}
\hline S.No & $\begin{array}{c}\text { Composite 1 } \\
\text { Ba+Ex } \\
(\mathbf{8 0 \%} \text { and 20\%) }\end{array}$ & $\begin{array}{c}\text { Composite 2 } \\
\text { Ba+Ex } \\
\text { (85\% and 15\%) }\end{array}$ & $\begin{array}{c}\text { Composite 3 } \\
\text { Ba+Ex } \\
\text { (90\% and 10\%) }\end{array}$ & $\begin{array}{c}\text { Composite 4 } \\
\text { Ba+Ex }\end{array}$ \\
\hline $\mathbf{9 5}$ and 05\%) \\
\hline 1 & 0.441 & 0.420 & 0.398 & 0.377 \\
\hline 2 & 0.456 & 0.439 & 0.421 & 0.404 \\
\hline 3 & 0.412 & 0.390 & 0.369 & 0.347 \\
\hline 4 & 0.427 & 0.407 & 0.387 & 0.367 \\
\hline 5 & 0.436 & 0.419 & 0.402 & 0.384 \\
\hline
\end{tabular}

Table 5: Thermal conductivity in W/K of composites of banana waste and epoxy as binder.

\begin{tabular}{|c|c|c|c|c|}
\hline S.No & $\begin{array}{c}\text { Composite 1 } \\
\text { Ba+WP } \\
\text { (80\% and 20\%) }\end{array}$ & $\begin{array}{c}\text { Composit 2 } \\
\text { Ba+WP } \\
(\mathbf{8 5 \%} \text { and 15\%) }\end{array}$ & $\begin{array}{c}\text { Composite 3 } \\
\text { Ba+WP } \\
\mathbf{( 9 0 \% ~ a n d ~ 1 0 \% ) ~}\end{array}$ & $\begin{array}{c}\text { Composit 4 } \\
\text { Ba+WP } \\
\text { (95\% and 05\%) }\end{array}$ \\
\hline 1 & 0.381 & 0.375 & 0.369 & 0.3623 \\
\hline 2 & 0.408 & 0.403 & 0.397 & 0.392 \\
\hline 3 & 0.361 & 0.352 & 0.343 & 0.334 \\
\hline 4 & 0.373 & 0.366 & 0.360 & 0.353 \\
\hline 5 & 0.396 & 0.389 & 0.381 & 0.374 \\
\hline
\end{tabular}

Table 6: Thermal conductivity in W/K of composites of Banana waste and waste plastic as binder.

composite material ranged from 0.334 to $0.408 \mathrm{~W} / \mathrm{K}$ (Tables 5 and 6). The thermal conductivity of the BA-WP decreased on decreasing the concentrations of binder. These values of thermal conductivity were also found satisfactory when capered to other researcher materials.

\section{Conclusion}

The samples of insulating materials were prepared with an aim to save energy loses in domestic as well as industrial applications. Different parameters such as size of sand and size of fibers were optimized. It was found that size of sand $<0.71 \mathrm{~mm}$ and size of fiber $<2 \mathrm{~mm}$ showed better results. Composite sample of Banana with waste plastic as binder was found with lowest thermal conductivity. Whereas the composite of banana with epoxy resin as binder was reported to have more than waste plastic. It was found that the density of insulation material of epoxy is denser than insulation material by waste plastic. It was also observed that with increase of binder concentration either epoxy or waste plastic, water absorption capacity reduced. This will also solve disposal problems of agricultural wastes and waste plastic reclaiming of the fill fields that are expensive and difficult. It also helps in recycling of the agricultural and plastic for better purposes.

\section{Acknowledgements}

The authors wish to express their sincere thanks for the lab facilities provided for this work in the Department of Chemical Engineering Mehran University o Engineering and Technology, Jamshoro, Pakistan.

\section{References}

1. Madurwara MV, Ralegaonkara RV, Mandavgane SA (2013) Application of agro-waste for sustainable construction materials: A review. Construction and Building Materials 38: 872-878

2. Nada AMA, El-Gendy AA, Mohamed SH (2010) Banana leaves as adsorbents for removal of metal ions from waste wate. Carbohydrate Polymers 82: 10251030.

3. Jawaid M, Khalil HPSA (2011) Cellulosic/synthetic fibre reinforced polymer hybrid composites: A review. Carbohydrate Polymers 86: 1-18.

4. Reddy N, Yang Y (2005) Biofibers from agricultural byproducts for industrial applications. TRENDS in Biotechnology 23: 22-27.

5. Venkateshwaran N, ElayaPerumal A, Alavudeen A, Thiruchitrambalam AM (2011) Mechanical and water absorption behaviour of banana/sisal reinforced hybrid composites. Materials and Design 32: 4017-4021. 
Citation: Parkash A (2015) Chemical and Mechanical Treatment of Banana Waste to Develop an Efficient Insulating Material. Biochem Anal Biochem 4: 220. doi:10.4172/2161-1009.1000220

6. Gore MA, Akolekar D (2003) Banana leaf dressing for skin graft donor areas. Burns 29: 483-486.

7. Curbelo MAG, Borges JH, Perez LMR, Delgado MAR (2011) Insecticides extraction from banana leaves using a modified QuEChERS method. Food Chemistry 125: 1083-1090.

8. Agoudjil B, Benchabane A, Boudenne A, Ibos L, Fios M (2011) Renewable materials to reduce building heat loss: Characterization of date palm wood. Energy and Buildings 43: 491-497.

9. Madurwar MV, Ralegaonkar RV, Mandaygane SA (2013) Application of agrowaste for sustainable construction materials: A review. Construction and Building Materials 38: 872-878.

10. Satyanarayana KG, Guimara JL, Wypych F (2007) Studies on lignocellulosic fibers of Brazil. Part I: Source, production, morphology, properties and applications. Composites: Part A 38: 1694-1709.
11. Alhuthali A, Low IM, Dong C (2012) Characterisation of the water absorption, mechanical and thermal properties of recycled cellulose fibre reinforced vinylester eco-nanocomposites. Composites: Part B 43: 2772-2781.

12. Shih YF, Xuan Cai J, Kuan CS, Hsieh CF (2012) Plant fibers and wasted fiber/ epoxy green composites. Composites: Part B 43: 2817-2821.

13. Li Y, Qin C, Lei Y (2012) The Study of Enzyme Hydrolysis Saccharification Process of Stems and Leaves of Banana. Energy Procedia 16: 223-228.

14. Ozkahraman HT and Bollatturk A (2006) The use of tuff stone cladding in buildings for energy conservation. Construction and Building Materials 20: 435440.

15. Linindt JWJ, Carraro AH, Heyliger PR, Choi C (2008) Application and feasibility of coal fly ash and scrap tire fibers as wood wall insulation supplements in residential buildings. Resources Conserve Recycle 45: 45-49. 